\title{
Mesoporous silica particles as potential carriers for protein drug delivery: protein immobilisation and the effect of displacer on $\gamma$-globulin release
}

Adejumoke Lara Ajiboye University of Greenwich, Central Avenue, Chatham Maritime, Kent, ME4 4TB; , Vivek Trivedi Medway School of Pharmacy, University of Kent, Central Avenue, Chatham Maritime, Kent, ME4 4TBCorrespondenceV.Trivedi@kent.ac.uk

\& John Mitchell University of Greenwich, Central Avenue, Chatham Maritime, Kent, ME4 4TB;

\section{Abstract}

The adsorption of $\gamma$-globulin was evaluated with experiments with silica particles marketed as Syloid AL1-FP (SAL), XDP-3150 (SXDP), and 244FP (SFP). The influence of pH, pore sizes, and degree of surface porosity on the extent of $y$-globulin immobilisation was examined. Protein adsorption on these particles was largely related to their surface porosity and pore sizes. The adsorption capacity was established to be greater with mesoporous SFP and SXDP particles at 474 and $377 \mathrm{mg} / \mathrm{g}$ respectively when compared to significantly low-porosity SAL $(16 \mathrm{mg} / \mathrm{g})$. Additionally, $\gamma$-globulin immobilisation was favoured at $\mathrm{pH}$ closer to iso-electric point. A key aim of this work was to better understand and improve the limited reversibility of protein adsorption. Protein desorption was found to be lower in simulated intestinal fluid (SIF) in comparison to $\mathrm{pH} 7.4$ phosphate buffer (PB). The use of displacer molecules [sodium dodecyl sulphate (SDS)/tween80/pluronic F127 (PF127)] promoted protein desorption from the adsorbent surface by the exchange mechanism. The PF127 provided substantial release in both studied condition but the highest release of $83 \%$ of $y$-globulin from SXDP was obtained with tween 80 in PB. The released protein was analysed with circular dichroism (CD) spectroscopy which indicated that the secondary structure of desorbed $y$-globulin was dependent on the $\mathrm{pH}$ and displacer molecule. The conformation largely remained unchanged when desorption was carried out in SIF but changed markedly in PB specially in the presence of SDS.

Keywords: $\gamma$-globulin, mesoporous silica, immobilisation, displacer, surfactant, protein drug delivery

1. Introduction

Mesoporous silica particles are the centre for a number of biomedical researches due to their stability, low toxicity, and ability to be functionalized with a variety of molecules and polymers [1]. These particles contain porous structure with hundreds of void channels (mesopores) that are able to absorb/encapsulate reasonably large amounts of biomolecules. Their distinctive properties, such as high surface area, large pore volume, and tuneable pore size with a narrow distribution make them readily suitable for various controlled release applications [2- 8]. The silica surface also plays an important part in the process of adsorption of molecules as it can allow for the formation of covalent, ionic or hydrogen bonding $[9,10]$. The current study investigates the influence of surface morphology on protein adsorption and desorption onto mesoporous particles.

Although the adsorption of protein on solid surfaces is a common phenomenon, it is also understood to be complicated due to the complex behaviour of the macromolecules during this process [11]. There is a need to answer important questions that arise in this aspect including why and how these biomolecules adsorb, the behaviour of adsorbed proteins either as individual molecules or in an ensemble, the influence of adsorption on the protein's biological function and, if there is a general mechanistic rule for the adsorption process [11]. Proteins can interact with particle surfaces with the help of various contributions from (i) electrostatic interaction between oppositely charged particles and protein molecules, (ii) specific hydrophobic dehydration at the surface of the adsorbent and/or 
parts of the protein molecules, (iii) structural readjustments by the protein molecule and (iv) van der Waals interactions $[12,13]$. The $\mathrm{pH}$ can play an important role in regulating the electrostatic interactions between adsorbate and adsorbent [14]. At their isoelectric point (IEP), proteins attain net neutral charge, therefore these molecules will be positively charged when the $\mathrm{pH}$ is lower and negatively charged at $\mathrm{pH}$ values greater than their IEP [15]. Electrostatic attraction may become a contributing factor at a pH lower than IEP because of the opposite charges on the protein and adsorbent surface such as silica. The opposite charge on protein and silica can result into an accelerated migration towards the surface with the consequent increase in the adsorption rates. However, the total amount of adsorbed protein is generally perceived to be maximised at the IEP due to the net zero charge on the protein, which facilitates higher adsorbate packing densities on a solid surface due to the reduced electrostatic protein-protein repulsion [15]. The current study presents an investigation into the adsorption behaviour of $\mathrm{y}$-globulin on silica with respect to $\mathrm{pH}$ change of the adsorption media.

$\gamma$-globulin was chosen as the model drug for this study. These glycoprotein molecules are generally known as immunoglobulins (Ig) and are produced by lymphocytes and plasma cells in the body [16]. They play a crucial role in eliciting immune response by specifically identifying and binding to antigens such as bacteria or viruses. There are five isotypes of immunoglobulins including $\lg G$, IgM, $\operatorname{IgA}$, IgD, and IgE based on the type of heavy chain found in the molecule i.e. gamma in IgG, mu in $\operatorname{lgM}$, alpha in IgA, epsilon in IgE, and delta in IgD [16]. Due to their structural flexibility and tendency to undergo conformational rearrangements upon particle surface contact, $\gamma$-globulins are classed as 'soft' proteins [17]. Hence, it was of importance for this work to also consider whether the structure of the protein was affected by the adsorption/desorption process.

In general, the immobilisation of biomolecules onto solid surfaces is often considered irreversible, as dilution/washing of the particle surface with chosen solvent does not usually lead to a substantial release $[18,19]$. This issue of lack of release can be addressed by the use of surface-active substances or displacers as long as they do not affect the protein conformation during or after desorption [20]. Displacers such as surfactants encourage desorption of the macromolecules by an exchange mechanism where the attached protein is competitively substituted from the adsorbent surface in favour of immobilisation of the smaller molecules [20]. Therefore, the effect of ionic/nonionic displacer molecules on $\mathrm{y}$-globulin desorption was also examined in this study.

In short, the rationale behind this work was to investigate the use of mesoporous silica as a potential drug delivery carrier for macromolecules as it is known that the immobilisation of proteins onto a solid surface can improve their stability without compromising their biological activity [21, 22]. The aim of this work was to determine adsorption and desorption of $\gamma$-globulin on silica whilst avoiding protein denaturation during the process. To effectively achieve this goal, the ideal parameters for surface immobilisation of $\gamma$-globulin (such as $\mathrm{pH}$ and protein concentration) were investigated for each adsorbent. Furthermore, the optimal parameters to allow maximum $\psi$-globulin desorption, especially the role of a displacer was also examined. The conformational changes that may occur to the $\gamma$-globulin molecules upon subsequent release from silica was evaluated using CD spectroscopy.

\section{Experimental}

\subsection{Materials}

Silica particles (SAL, SXDP, and SFP) were kindly supplied by Grace Davison, USA. Bovine $\gamma$-globulin was purchased from Sigma Aldrich, UK and used without any further purification. The lyophilised $y$ globulin was listed to be a mixture of $\operatorname{IgG}(80 \%), \operatorname{IgM}(10 \%)$, and $\lg A(<10 \%)$, with a total molecular 
weight of $150 \mathrm{kDa}$. All other chemicals ( $\mathrm{NaOH}, \mathrm{HCl}$, SDS, PF127, tween 80, Na2HPO4, and KH2PO4) were of analytical grade, and deionised water was used throughout the study.

\subsection{Methods}

\subsubsection{Evaluation of $\gamma$-globulin adsorption}

Prior to the adsorption studies, the IEP of $\gamma$-globulin was determined to understand the influence of $\mathrm{pH}$ on the macromolecule's net charge. Initially, the zeta potential for $0.1 \%$ aqueous solution of $\gamma$ globulin was obtained by titration at $25^{\circ} \mathrm{C}$ using $0.3 \mathrm{M} \mathrm{NaOH}$ and $\mathrm{HCl}$ as titrants with a Malvern MPT-2 autotitrator (Malvern Instruments Ltd, UK). IEP was determined by plotting a graph of $\mathrm{pH}$ against the zeta-potential values.

The maximum adsorption of $\gamma$-globulin onto each silica particle was determined with protein solutions in PB at various concentrations ( 0.5 to $24 \mathrm{mg} / \mathrm{ml}$ ) and $\mathrm{pH}(\mathrm{pH} \mathrm{5}, 6,7.4$ or 9). The protein adsorption at each $\mathrm{pH}$ and concentration was determined with $10 \mathrm{ml}$ of $\mathrm{\gamma}$-globulin solution and $400 \mathrm{mg}$ of the adsorbent particles at room temperature $\left(23 \pm 2^{\circ} \mathrm{C}\right)$ under stirring at $250 \mathrm{rpm}$ for 4 hours. Subsequently, the protein content remaining in the media was evaluated by ultravioletvisible (UV-Vis) (Cary 100 UV-Vis spectrometer, Agilent Technologies, UK) spectroscopy at $278 \mathrm{~nm}$. The quantity of adsorbed $\gamma$-globulin was estimated by subtracting the amount present in the media after immobilisation from the initial protein content in the solution. Following maximum adsorption studies, $\gamma$-globulin-immobilised particles were prepared with $0.5 \mathrm{mg} / \mathrm{ml}$ of protein solution for SAL and $10 \mathrm{mg} / \mathrm{ml} \mathrm{SXDP} / \mathrm{SFP}$. The ratio between protein solution and silica was kept at 1:40. The proteinadsorbed particles were separated from the media via centrifugation at $3700 \mathrm{rpm}$ (Centrifuge 5430, Eppendorf, UK) for $10 \mathrm{~min}$ and freeze-dried at $-55^{\circ} \mathrm{C}$ under deep vacuum using a ScanVac CoolSafe freeze dryer (LaboGene ApS, Denmark).

\subsubsection{Characterisation of solid particles}

Subsequent to $\gamma$-globulin adsorption, the point of zero charge (PZC) for untreated and proteinimmobilised silica particles was determined by $\mathrm{pH}$ titration as described above for $\mathrm{\gamma}$-globulin.

Nitrogen (N2) adsorption and desorption isotherms were obtained at relative pressure (P/Po) from 0.05 to 1 on a Gemini 2380 instrument (Micromeritics Instrument Corporation, UK) for untreated and protein-immobilised silica particles. The samples were degassed prior to the measurements with nitrogen at 100 and $40^{\circ} \mathrm{C}$ for protein-free and $\gamma$-globulin-adsorbed particles respectively for approximately 12 hours. The specific surface area (SSA) was calculated as per the Brauner-EmmettTeller (BET) model while the pore volume and distribution were determined by Barrett, Joyner and Halenda (BJH) model $[23,24]$.

Additionally, the attenuated total reflection- Fourier transform infra-red (ATR-FTIR) spectra of the solid particles were obtained using a Spectrum Two FTIR spectrometer (Perkin Elmer, UK). The spectra were collected from $4000-400 \mathrm{~cm}-1$ range in transmission mode with the resolution of $8 \mathrm{~cm}-1$ whilst collecting approximately 16 scans per spectrum.

\subsubsection{Evaluation of $\gamma$-globulin desorption}

To study the influence of $\mathrm{pH}$ on the rate of protein release, desorption of $\gamma$-globulin was performed in $\mathrm{pH} 6.8$ simulated intestinal fluid (SIF) and in $\mathrm{pH} 7.4 \mathrm{~PB}$ at $37 \pm 2{ }^{\circ} \mathrm{C}$ with or without the presence of displacers (0.1\% SDS/tween 80/PF127). For all experiments, $100 \mathrm{mg}$ of protein-immobilised particles were suspended in $50 \mathrm{ml}$ of desorption media and stirred at $250 \mathrm{rpm}$. The concentration of $\gamma^{-}$ globulin at $5,15,30,45,60,90,120,150$, and 240 minutes were determined by UV-Vis analysis on 
$4 \mathrm{ml}$ aliquots. The total volume of desorption media was kept constant throughout the experiment by the addition of $4 \mathrm{ml}$ of fresh buffer after every withdrawal.

Subsequently, the structural stability of desorbed $\gamma$-globulin was studied by CD spectroscopy using a Chirascan qCD spectrometer (Applied Photophysics Ltd., UK). CD analysis was carried out with a matched pair of rectangular quartz cells of $1 \mathrm{~mm}$ optical path length under nitrogen. The spectra of the fresh and desorbed protein in respective buffers were recorded as a measurement of four repeats in the range of $180-260 \mathrm{~nm}$ at $20^{\circ} \mathrm{C}$ with a time per-point of 2.5 seconds. The $C D$ data for $\gamma$ globulin was obtained by subtracting the spectrum of the buffer from that of the protein solution and compared with the spectrum of fresh protein solution in the same buffer.

\section{Results and Discussion}

\subsection{Surface analysis of silica particles}

The surface porosity of silica particles was investigated by nitrogen sorption experiments. The recorded BET isotherms for both SFP and SXDP particles were classed as a Type IV isotherm due to their characteristic $\mathrm{H} 1$ hysteresis loop, thus suggesting that they are mesoporous (pores of widths between 2 and $50 \mathrm{~nm}$ ) in nature [25-27]. The shape of the hysteresis loop is widely known to correlate to pore structures including pore size distribution, pore geometry and connectivity of mesoporous materials. Type $\mathrm{H} 1$ is usually related to porous materials that have agglomerates or distinct cylindrical-like pore channels of nearly uniform spheres [26, 27]. On the other hand, the lack of hysteresis and the reversible Type II isotherm for SAL indicated that they were generally nonporous or contained extremely small pores $[26,27]$. Additionally, the amount of nitrogen adsorbed $(260 \mathrm{~cm} 3 / \mathrm{g} \mathrm{STP})$ onto the surface of SAL was also lower than that recorded for SFP, and SXDP (892 and $996 \mathrm{~cm} 3 / \mathrm{g}$ STP respectively) indicating that the SAL particles have a reduced nitrogen adsorption capacity in comparison to others.

The SSA calculated according to the BET equation, pore volume and diameter deduced by BJH model along with other characteristics of silica particles used in this study are presented in Table 1.

The SSA for SAL particles was significantly higher at $767 \mathrm{~m} 2 / \mathrm{g}$ whereas, the SSA of SFP and SXDP was comparable at 289 and $258 \mathrm{~m} 2 / \mathrm{g}$ respectively. The pore sizes and volume followed an ascending trend of SAL < SFP < SXDP which is also similar to that for the quantity of nitrogen adsorbed to the surface of the particles. The bulk density and size of SFP was the lowest between three types of particles used in this study. Whereas, SXDP has the largest particle size of $50 \mu \mathrm{m}$ and SAL has the highest bulk density of $566 \mathrm{~g} / \mathrm{L}$.

\subsection{Evaluation of $\psi$-globulin adsorption}

Adsorption isotherms for SFP, SXDP, and SAL are presented in Figure 1.

The plots for SFP and SXDP showed a well-defined plateau for the immobilisation of $y$-globulin onto the surface of these solid particles. Adsorption isotherms with a well-defined plateau value are typical for immobilisation of macromolecules on solid sorbent surfaces and relate to the transition from partial to full surface coverage by protein $[19,22,28]$. As presented in Figures $1 A$ and $B$, there was a sharp rise in the $\gamma$-globulin $(\mathrm{mg} / \mathrm{g})$ adsorption with the increase in initial protein concentration ( 2 to $10 \mathrm{mg} / \mathrm{ml}$ ) at all $\mathrm{pH}$ values. In general, adsorption became relatively slower or steadied at the concentrations above $10 \mathrm{mg} / \mathrm{ml}$. A plateau was achieved at or above $16 \mathrm{mg} / \mathrm{ml}$ with SXDP at all pH values and $18 \mathrm{mg} / \mathrm{ml}$ with SFP at pH 6 and 7.4. The plateau concentration for SFP was lower $(16 \mathrm{mg} / \mathrm{ml})$ at $\mathrm{pH}$ 9. An equilibrium adsorption was not achieved with SFP at $\mathrm{pH} 5$ but experiments at protein concentrations above $24 \mathrm{mg} / \mathrm{ml}$ were not performed to allow for the comparative data with 
other $\mathrm{pH}$ values. The rapid increase at initial concentrations ( 2 to $10 \mathrm{mg} / \mathrm{ml}$ ) is associated with high affinity of protein for the sorbent and the plateau signifies saturation of the silica surface with a closed-packed monolayer of macromolecules. Therefore, any additional rise in the protein concentration thereafter usually does not lead to further increase in adsorption unless multilayer adsorption is expected.

In contrast to both SFP and SXDP there was limited increase in the quantity of adsorbed $\gamma$-globulin with increasing protein concentration $(\mathrm{mg} / \mathrm{ml}$ ) for SAL (Figure $1 \mathrm{C}$ ). There was no increase in the amount of protein adsorption at pH 5, 7.4 and 9. However, a sudden surge in adsorbed protein could be seen at pH 6 with $2 \mathrm{mg} / \mathrm{ml} \mathrm{\gamma}$-globulin concentration which may suggest formation of multilayers [29]. The experiment was stopped at $2 \mathrm{mg} / \mathrm{ml}$ because over $70 \%$ of free protein was still present in the supernatant after the incubation time of 4 hours. The quantity of protein adsorbed onto SAL ranged from only 6 to $16 \mathrm{mg} / \mathrm{g}$ depending on $\gamma$-globulin concentration ( 0.5 to $2 \mathrm{mg} / \mathrm{ml}$ respectively) and $\mathrm{pH}$. Thus, implying that immobilisation of $\gamma$-globulin onto SAL may be limited due to the presence of inaccessible pores.

The highest $\gamma$-globulin adsorption of $474 \mathrm{mg} / \mathrm{g}$ was recorded for SFP and the lowest of $16 \mathrm{mg} / \mathrm{g}$ with SAL. This suggests a correlation between the surface properties particularly porosity and pore size of the adsorbent on protein adsorption [30- 32]. The presence of relatively smaller pores $(2.5 \mathrm{~nm})$ on SAL was confirmed by BET as shown in Table 1 and Figure 2B. The presence of small pores although results in high specific surface area (Figure $2 \mathrm{~A}$ ) as determined by N2 adsorption but most of these pores remain inaccessible to $\gamma$-globulin molecules due to their hydrodynamic size. On the other hand, the protein adsorption on SXDP was comparatively lower $(373 \mathrm{mg} / \mathrm{g})$ than SFP despite the presence of relatively larger pores and slightly higher pore volume. The estimated hydrodynamic radius of $y$-globulin is known to be $5.29 \mathrm{~nm}$ indicating requirement of large spaces for it to be able to successfully adsorb onto available pores [33]. Both SFP (Figure 3B) and SXDP (Figure 4B) contain pores much larger than the hydrodynamic diameter of the protein. Hence, it can be assumed that mesopores on these particles accommodate multiple $\gamma$-globulin molecules but the ratio of mesopore volume and the number of adsorbed protein molecules remains relatively constant for both SFP and SXDP. In other words, although the average pore size is higher on SXDP $(22.2 \mathrm{~nm})$ in comparison to SFP $(19.1 \mathrm{~nm})$ but the pore volume increase is not enough to accommodate more $\gamma$-globulin molecules in available pores [34]. Nonetheless, both SFP and SXDP are mesoporous in nature with a comparatively high pore volume and large pores in comparison to SAL. Therefore, it can be confirmed that the immobilisation of $y$-globulin onto these inorganic particles was strongly influenced by the porosity and, the type volume and size of pores.

In general, highest immobilisation of $\mathrm{\gamma}$-globulin was observed at $\mathrm{pH} 5$ and 6 while lowest at $\mathrm{pH} 9$, which can be attributed to the influence of net charge on the protein at these conditions. The IEP of $\gamma$-globulin was determined to be at $\mathrm{pH}$ 6.50-6.60. It contained comparatively high net negative charge $(\sim-16 \mathrm{mV})$ at $\mathrm{pH} 9$ than $\mathrm{pH} 7.4(\sim-9 \mathrm{mV})$. It was positively charged at $\mathrm{pH} 5(\sim+12 \mathrm{mV})$ and almost neutral at $\mathrm{pH} 6(\sim+3 \mathrm{mV})$. This suggested that in terms of possible electrostatic interactions with negatively-charged adsorbent (silica), $\mathrm{pH} 5$ can be the most favoured due to opposite net charges and least at pH 9 owing to protein-protein and protein-silica repulsion [35- 37]. However, electrostatic interactions cannot be suggested as the primary mechanism for $\gamma$-globulin adsorption onto the studied particles, as immobilisation still occurs to a great extent for both SFP and SXDP at

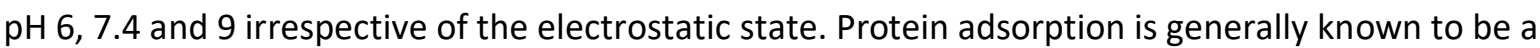
net result of various interactions including van der Waals forces, hydrogen bonding, hydrophobic interactions and the electrostatic forces. This is attributed to the fact that proteins are large molecules with a number of active sites that can allow for these interactions to occur simultaneously 
[38]. Moreover, the hydrodynamic size of protein molecules depends on the solution $\mathrm{pH}$, which can also have significant impact on its adsorption in the mesopores.

The adsorption data for SFP, SXDP, and SAL were fitted to Langmuir and Freundlich models [39] and the $R 2$ values are presented in Tables 2 and 3 respectively.

In general, the adsorption isotherms for silica particles were a better fit to Langmuir model suggesting monolayer coverage of $\mathrm{\gamma}$-globulin at most $\mathrm{pH}$ conditions on the surface of studied adsorbent particles $[19,39]$. The Langmuir isotherm describes a dynamic protein adsorption process where it is assumed that (i) a monolayer is formed at the adsorbent surface (ii) there are no interactions amongst adsorbed molecules, and (iii) no conformational change occurs to the protein structure upon adsorption [39]. On the other hand, Freundlich's isotherm can be used to certify several immobilisation processes permitting for one or more interactions either between adsorbed molecules or between the adsorbed molecules and sorbent surface [39].

\subsection{Characterisation of $\gamma$-globulin-adsorbed silica particles}

Nitrogen sorption isotherms () were obtained for protein-adsorbed SFP (Figure 3A), SXDP (Figure $4 \mathrm{~A}$ ), and SAL (Figure 2A) particles, and in general, there were no changes to the shape of the isotherms post $\gamma$-globulin adsorption. The plots for protein-loaded SFP and SXDP particles remained class Type IV indicating that they still retained their mesoporous nature after immobilisation of $\gamma$ globulin. The isotherm for protein adsorbed-SAL also remained the same (Type II), still appearing to be non-porous/consisting of very small pores as before [25- 27]. However, as recorded in Table 4, there was a decrease in the SSA, pore volume and diameter for $\gamma$-globulin-adsorbed SFP and SXDP particles, when compared to BET data obtained before protein immobilisation.

The nitrogen adsorption (cm3/g STP) decreased by more than 50\% for SFP and about $40 \%$ for SXDP for $\mathrm{Y}$-globulin-adsorbed particles. In contrast to SFP and SXDP, the differences to the surface properties of SAL were minimal, with the SSA reducing only by $8 \%$ post protein immobilisation. In summary, amongst the three silica, the differences recorded after $\gamma$-globulin immobilisation was highest for SFP and lowest for SAL, which also agrees with the protein adsorption data. The changes observed to the surface properties of the silica particles post-immobilisation is related to the presence of adsorbed protein molecules at the adsorbent surface $[40,41]$. A reduction in the nitrogen adsorption and SSA for the protein adsorbed-particles suggest that $\gamma$-globulin molecules now occupy the adsorbing surface; hence, there was less room for oncoming nitrogen molecules. Similarly, the decrease in the pore volume after protein adsorption also indicates reduced space or inaccessibility of pores for nitrogen molecules due to the surface saturation by $\gamma$-globulin on the surface [42]. SSA as determined by N2 adsorption can be misleading with respect to expected protein adsorption. $\gamma$-globulin is a macromolecule meaning that the total calculated BET surface area could rarely match the accessible surface area for it onto adsorbent particles [42]. Hence, SSA alone must not be used to predict protein immobilisation on porous materials. The maximum changes for SFP was likely due to the highest protein adsorption on to its surface than other silica particles. The protein adsorption is also expected to alter the surface charges on these particles. Hence, net surface charge on bare and protein-covered silica was determined, as presented in Table 5.

Prior to protein immobilisation, the PZC for untreated silica particles was in the range of $\mathrm{pH} 0.80$ to 1.60. The upward shift to the PZC values after $\gamma$-globulin adsorption confirmed the presence of protein on the surface and, also suggested that the surface-charge of these particles was influenced by the presence of adsorbed protein molecules [43]. 
ATR-FTIR analysis was performed on protein adsorbed silica to assess $\gamma$-globulin immobilisation and if any changes to the protein conformation occurred after the adsorption. Typically, the secondary structure of a protein can be estimated by FTIR analysis based on the absorption of infra-red (IR) radiations by their peptide bonds [44]. The ATR-FTIR spectra for native $\gamma$-globulin and proteinadsorbed silica particles are presented in Figure 5. The typical absorption bands for silica can be observed near $1070 \mathrm{~cm}-1$ (stretching vibrations of Si-O bonds), $970 \mathrm{~cm}-1$ (non-bonded Si-O-), at $800 \mathrm{~cm}-1$ (bending vibrations of Si-O bonds) and $450 \mathrm{~cm}-1$ (bending vibrations of Si-O-Si bonds) [45, 46].

For the free $\gamma$-globulin, the amide I and II bands can be observed at 1633 and $1518 \mathrm{~cm}-1$ respectively. Generally, the amide I band near 1650 to $1658 \mathrm{~cm}-1$ represents an $\alpha$-helical structure, whereas for $\beta$-sheet these appear between $1620-1640 \mathrm{~cm}-1$ [47, 48]. Thus, indicating a secondary structural arrangement of primarily $\beta$-sheets for pure $\gamma$-globulin. A slight shift to the amide I band to 1649, 1647 and $1636 \mathrm{~cm}-1$ was observed for SFP, SXDP and SAL particles respectively. The peak shift observed with SFP and SXDP may indicate possible conformational changes to the hydrogen bonding in the peptide linkages found in the secondary structure of adsorbed $\psi$-globulin [48]. Protein molecules can undergo structural re-arrangements upon interaction with the solid surface, which may become a significant problem if they do not regain their original conformation upon desorption or if this results in the loss of the protein's biological functions [48]. In comparison to the native protein, there was also a reduction in the intensity of amide I peak as observed for protein-adsorbed silica particles. The reduction in intensity can be related to the surface concentration of $\gamma$-globulin as it rises with the increase in the adsorbed surface protein (SFP > SXDP > SAL).

\subsection{Evaluation of $\gamma$-globulin desorption}

Desorption of $\gamma$-globulin from protein-immobilised SFP and SXDP in SIF and PB with or without the presence of the displacer is presented in Figure 6 and Figure 7. The protein release from SAL particle was minimal, hence those results were ommitted in this section.

The detachment of protein from SFP took place very slowly in the absence of displacers in both SIF and PB. Only $6 \pm 3 \%$ and $22 \pm 3 \%$ of $\gamma$-globulin was released in SIF and at PB respectively after 90 minutes. This finding not only confirmed the high affinity of $\gamma$-globulin for SFP, but also suggested that protein adsorption on these particles may be mostly irreversible. However, desorption rate was greatly improved with the presence of surface-active molecules in the media. Table 6 contains a summary of protein release at $\mathbf{2 4 0}$ minutes which clearly illustrates the impact of the displacer and $\mathrm{pH}$ on desorption.

The protein detachement attained by surface-active molecules is typically dependent on their type and concentration, along with the surface properties of the adsorbent. Furthermore, the initial surface loading parameters including protein concentration and its contact time with the solid surface also plays a role in their effectiveness $[49,50]$. The protein desorption was slightly higher with SDS in both SIF and PB with 52\% and 77\% respectively after 240 minutes. The non-ionic Tween 80 provided the lowest protein desorption $(34 \%)$ at $\mathrm{pH} 6.8$. However, the percentage release at $\mathrm{pH}$ 7.4 was similar irrespective of the surface-active agents used as a displacer. The variations between desorption of $\gamma$-globulin can be linked to the nature and molecular weight, hydrophobicity and molar volume of these molecules [50]. Anionic surfactant such as SDS with negatively charged head groups are known to promote high protein desorption [50]. Whereas, non-ionic molecules such as Tween 80 and PF127 can have comparatively reduced effect on the desorption of immobilised protein. The slight differences between protein desorption by PF127 and Tween 80 could also be attributed to disimilarities in the hydrophobicity of their hydrocarbon chains [50]. 
Similarly, the desorption of $y$-globulin from SXDP particles with and without displacers are presented in Figure 7. As seen earlier, the protein release without surfactants was only $2 \%$ and $28 \%$ at $\mathrm{pH} 6.8$ and 7.4 respectively in 240 minutes. The release rate increased significantly with the addition of surfactants where a steady protein desorption was obtained with time.

Introduction of SDS in the media resulted in 50\% and 65\% desorption after 240 minutes at pH 6.8 and 7.4 respectively. Whereas, PF127 and Tween 80 containing buffers provided protein desorption of $46 \%$ and $33 \%$ at $\mathrm{pH} 6.8$ respectively. The desorption results at 240 minutes are summarized in Table 7.

A significant increase was observed at pH 7.4 with the final protein release reaching to $78 \%$ and $83 \%$ for PF127 and Tween 80 respectively. Like SFP, the higher desorption obtained for SXDP was in the presence of SDS at pH 6.8 in comparison to PF127 and Tween 80. On the contrary, Tween 80 led to the maximum and SDS inclusion resulted in the lowest desorption at $\mathrm{pH} 7.4$. This trend at $\mathrm{pH} 7.4$ does not fall in line with the one recorded for SFP but desorption in the presence of PF127 remains consistent for both silica particles. The consistency associated with PF127 as a displacer in both cases could be attributed to it's amphiphilic nature and large molecular weight in comparison to both SDS and Tween 80 [51,52]. SDS's propensity to interact with polar functionalities on $\gamma$-globulin and slight variations in surface propoerties of silica (e.g. presence of large pores on SFP silica) may be the possible reasons behind the differences in the protein desorption and slightly different trend with respect to the type of displacer and silica used in this study.

The desorption from both particles was highest at $\mathrm{pH} 7.4$ regardless of the presence and type of displacer in the buffer. Therefore, suggesting that the release process from silica is definitely influenced by the $\mathrm{pH}$ of the media and the inclusion of a displacer promotes this further. This increase in the total protein release and desorption rate could be related to the presence of the net charge on $\mathrm{\gamma}$-globulin molecules at these $\mathrm{pH}$ [53]. For example, higher electrostatic repulsion between silica and protein could be expected at pH 7.4 due to net negative charge on both entities. The known mechanisms of action for protein displacement by a surfactant molecule include; desorption by replacement or enhanced solubilization of macromolecules due to the presence of surface active agents [54]. Removal of proteins by the replacement mechanism occurs when there is a significant interaction between the adsorbent surface and surfactant molecules in comparison to interactions between protein and surfactant [54]. As proteins typically have weak interactions with non-ionic entities like Tween 80 and PF127, replacement could be the favoured mechanism for desorption instead of solubilization. However, ionic surfactants like SDS may interact strongly with charged side-chains of the protein and result 'in part' desorption via solubilization [54, 55].

In summary, presence of a displacer at both $\mathrm{pH} 6.8$ and 7.4 resulted in the higher protein desorption desorption. The maximum $\mathrm{\gamma}$-globulin release of $83 \%$ from SXDP was obtained from the $\mathrm{pH} 7.4$ media containing tween 80 . PF127 was the most intresting choice of diplacer in this work which resulted in similar release of $\gamma$-globulin from both SXDP and SFP. Neverthelss, the incomplete release of the adsorbed $\gamma$-globulin also confirms that there is always a population of protein molecules that are irreversibly adsorbed on the solid surface or inaccessible to the media [56]. In relation to the release of immobilised proteins, it was observed that the silica particles (SFP) with higher protein population on the surface generally retained a smaller fraction when exposed to the buffer-displacer solution after 3 or 4 hours. This could be attributed to the protein's ability to adapt and improve its contact with the unoccupied portions of the less-densely packed surfaces, thereby making its release more difficult [50]. It is important to remember that desorption of soft macromolecules is equally complicated as their adsorption. Therefore, multiple mechanisms acting simultaneously can be expected to promote desorption, similar to adsorption as discussed earlier. 


\subsection{Stability of $\gamma$-globulin after desorption}

The protein molecules may result in the change in their conformation to easily adapt to the surface upon adsorption onto a solid [22]. Thus, there is always a possibility that desorbed protein may not retain or reverse back to its orginal structure, and consequently looses its functionality [57]. Hence, the conformational intergrity of $\gamma$-globulin upon subsequent displacement was investigated using $C D$ specstroscopy. The CD spectra for $\mathrm{y}$-globulin desorbed at $\mathrm{pH} 6.8$ from SFP and SXDP are presented in Figure 8.

The slope of spectra collected for $\mathrm{y}$-globulin desorbed from SFP and SXDP at pH 6.8 did not differ from that of the native protein. The maximum positive and negative ellipticity values at 201 and $218 \mathrm{~nm}$ respectively indicate that desorbed protein largely retained its $\beta$-sheet conformation [58]. The CD data obtained for SFP contained no differences in the ellipticity values for desorbed $\gamma$ globulin when compared to native protein. However, considerable changes were obtained for protein desorbed from SXDP with Tween 80 in comparison to native protein where the shape of its spectra was nearly lost. This indicated a major change to the desorbed $y$-globulin conformation in the presence of Tween 80 . There were minor differences in the data collected for released protein in the media containing SDS and PF127. This can be attributed to the slight irregularities in estimation of the $\gamma$-globulin concentration for the analysed samples impacting the CD absorbance data and consequently the corrected molar elipiticity values [58]. However, lack of any shift in the minima and maxima on the spectra for both SDS and PF127 would suggest that desorbed $y$-globulin retained its native conformation and presence of these diplacers in the release media did not have any unwanted effect.

The CD spectra for protein desorbed at pH 7.4 from SFP and SXDP with surface-active molecules are presented in Figure 9.

In contrast to the data obtained at $\mathrm{pH} 6.8$, the spectra for $\mathrm{\gamma}$-globulin molecules desorbed at $\mathrm{pH} 7.4$ differed considerably from that of the native protein. Aside from differences in the ellipticity values, for $\gamma$-globulin desorbed with PF127 and Tween 80, there was either a loss of the maxima at $201 \mathrm{~nm}$ (as seen with SFP) or shift in this peak as observed with SXDP particles. The minima at $218 \mathrm{~nm}$ for protein desorbed by both PF127 and Tween 80 retained its position when compared to the native spectra. On the other hand, the spectra for $y$-globulin desorbed by SDS from SFP and SXDP completely lost its maxima at $201 \mathrm{~nm}$ and there was also a significant shift in the position of the minima. This indicated conformational changes to the secondary structure of released $\gamma$-globulin at this $\mathrm{pH}$ and considerable loss of $\beta$-sheets due to the presence of ionic surface active agent in the desorption media. This could be related to the interactions of released protein with surfactant molecules in the media. SDS is an anionic surfactant that strongly binds to the positively charged and the hydrophobic residues of proteins through its sulfate groups and alkyl chains respectively, which could result in the partial to complete unfolding of the protein [59]. On the other hand, although non-ionic molecules like Tween 80 and PF127 could have weak hydrophobic interactions with released $\gamma$-globulin, they tend to interact more with each other rather than the protein thus limiting their denaturing effects on the structure of the macromolecule [59]. Furthermore, ampiphilic substances like PF127 and Tween 80 are known to mask hydrophobic sites of the protein which could have stabilizing effects on the protein structure by preventing aggregation and surface adsorption [59-61]. Moreover, as the deviation in CD spectra were more pronounced for protein desorbed at $\mathrm{pH} 7.4$ than $\mathrm{pH} 6.8$, it would seem that the $\mathrm{pH}$ also plays an important role in the instability of released $\gamma$-globulin caused by the possible electrostatic interactions at higher $\mathrm{pH}$ [62]

\section{Conclusion}


The effect of $\mathrm{pH}$ and surface porosity on immobilisation of $\mathrm{\gamma}$-globulin onto SFP, SXDP, and SAL was investigated where maximum adsorption was obtained for SFP $(474 \mathrm{mg} / \mathrm{g})$ followed by SXDP

$(377 \mathrm{mg} / \mathrm{g})$. Protein adsorption on silica was favourable at a $\mathrm{pH}$ nearer to the IEP of $\mathrm{Y}$-globulin $\mathrm{pH} 6$. The influence from the electrostatic interactions between the adsorbent surface and the adsorbing molecules was found to be minimal during the adsorption process. The porosity and the pore sizes were the most important parameters during adsorption where particles with large pores (SFP, and SXDP) immobilised significantly higher quanities of protein. Desorption of immobilised $\gamma$-globulin from SFP and SXDP particles was minimal but it was $\mathrm{pH}$ dependent where increase in $\mathrm{pH}$ led to higher protein release. The addition of a displacer in the media enhanced the protein release reaching to above $80 \%$. However, loss in protein conformation was also observed especially in the presence of anionic displacer at $\mathrm{pH}$ 7.4. Hence, it is important to select the displacer carefully, and this work clearly indicates that large amphiphilic polymers such as pluronics instead of anionic surfactants should be the preferred choice for the desorption of $\gamma$-globulin from silica surface to avoid protein denaturation. This study has successfully investigated the importance of factors such as pore size and volume of mesoporous materials in the adsorption and desorption of $\gamma$-globulin, but further investigation may still be necessary to ascertain biological functionality of released protein.

Figure 1: Adsorption isotherms for $\gamma$-globulin onto (A) SFP, (B) SXDP and (C) SAL particles
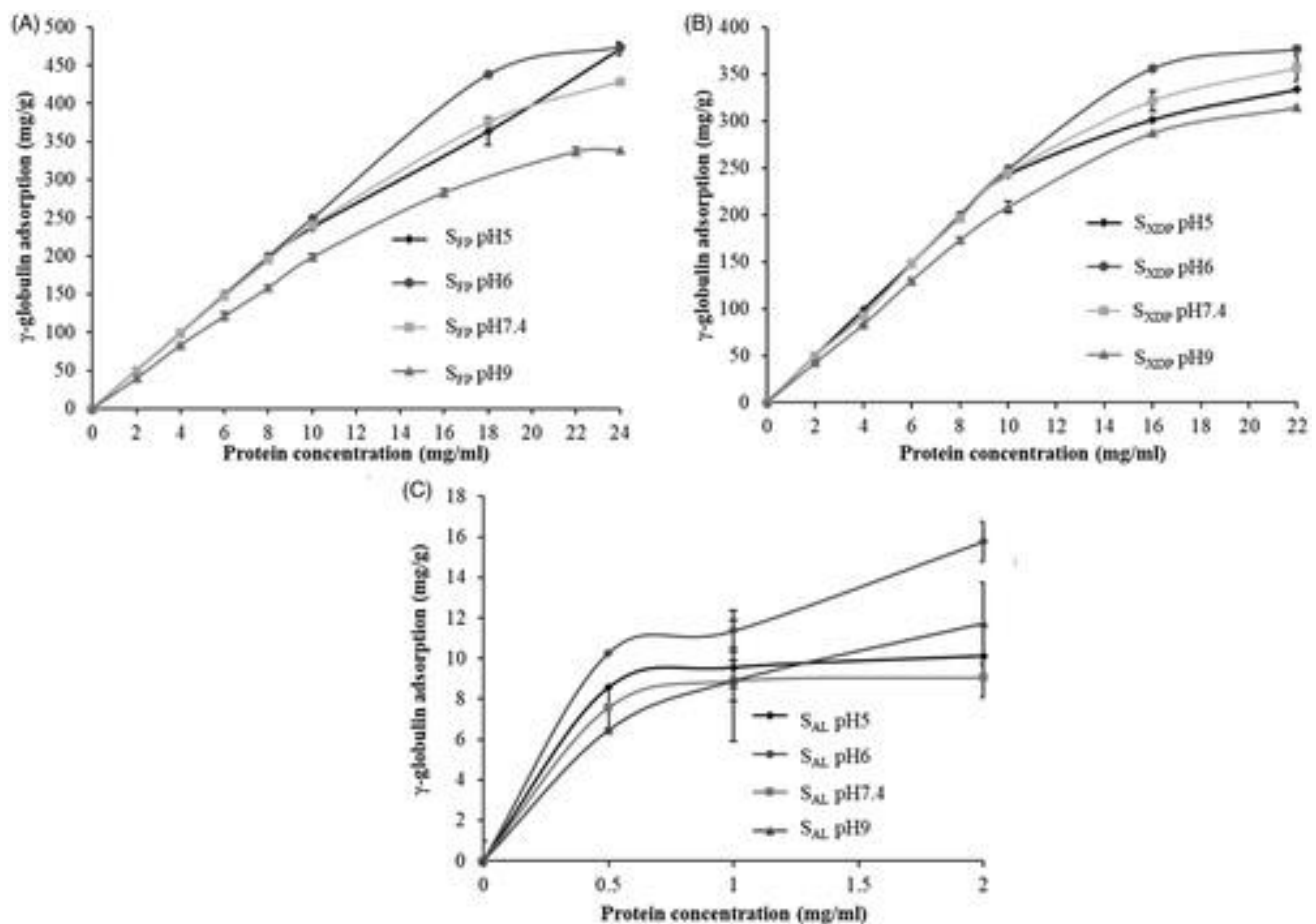
Figure 2: Nitrogen adsorption isotherm (A) and pore size distribution (B) for SAL and $\gamma$-globulin-SAL particles
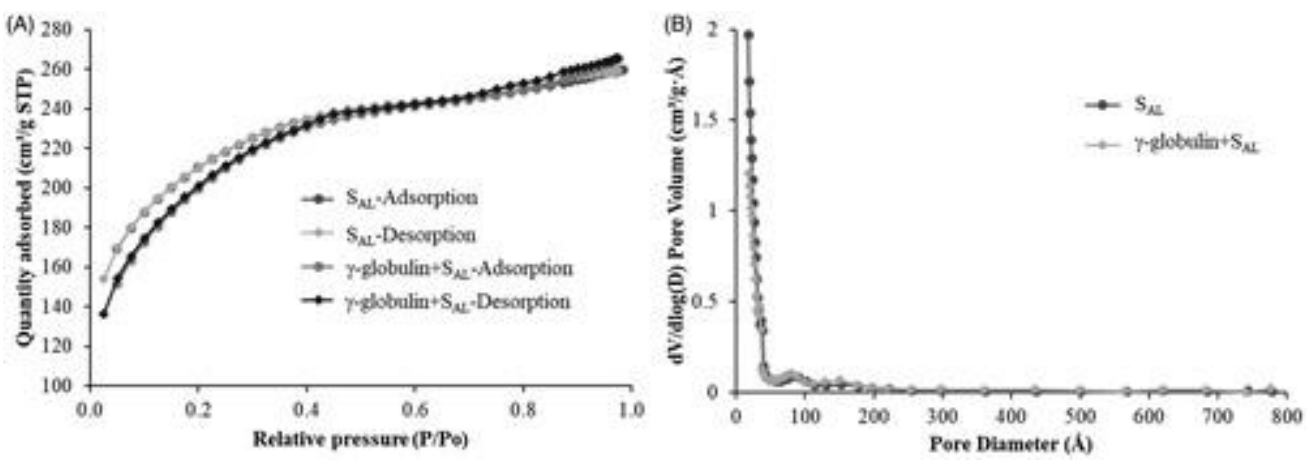

Figure 3: Nitrogen adsorption isotherm (A) and pore size distribution (B) for SFP and $\gamma$-globulin-SFP particles
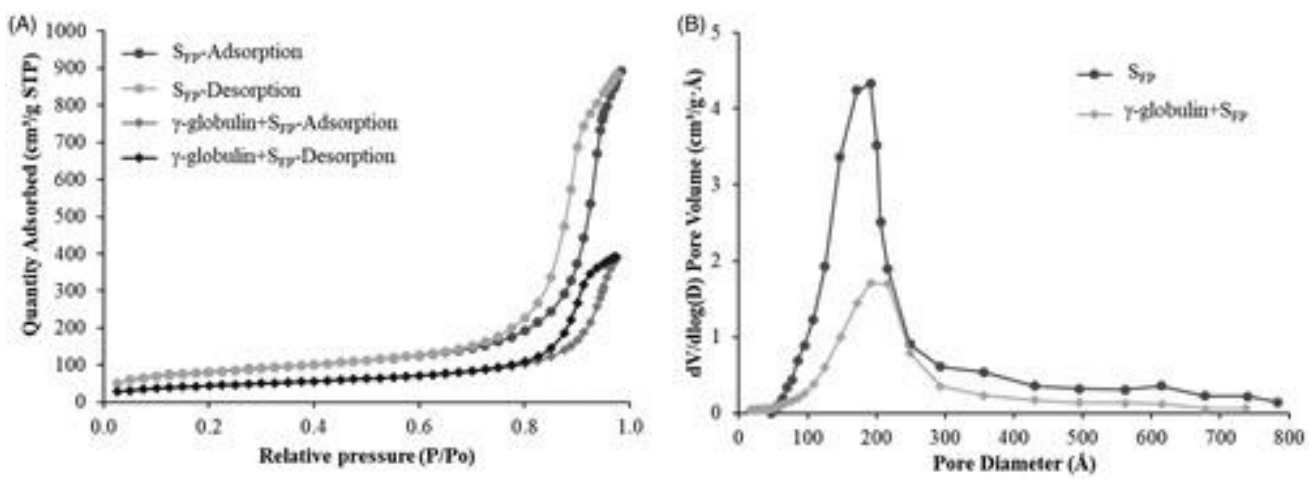

Figure 4: Nitrogen adsorption isotherm (A) and pore size distribution (B) for SXDP and $\gamma$-globulinSXDP particles
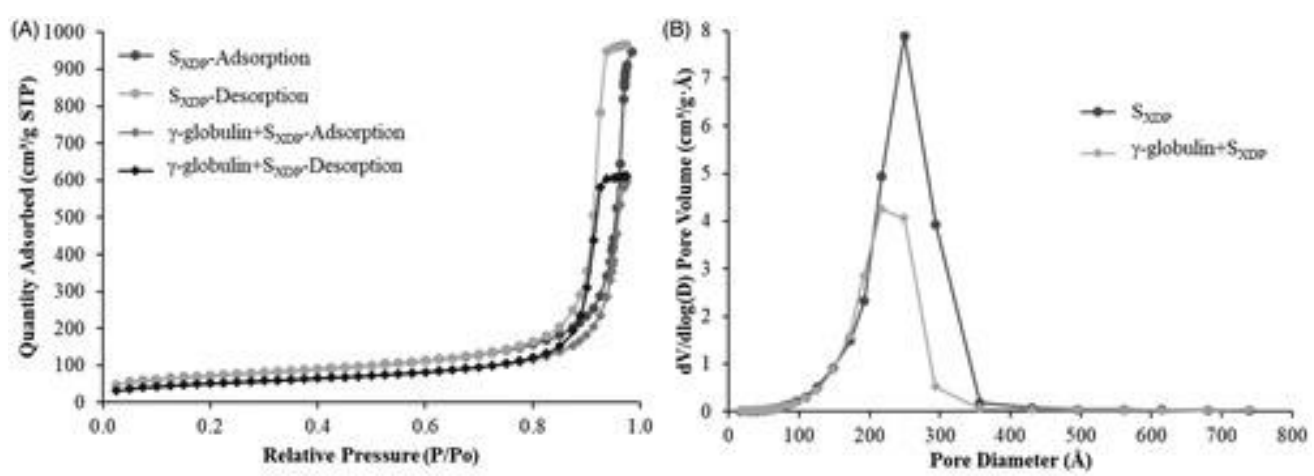
Figure 5: ATR-FTIR spectra for (i) $\gamma$-globulin, and $\gamma$-globulin- (ii) SFP (iii) SXDP (iv) SAL.

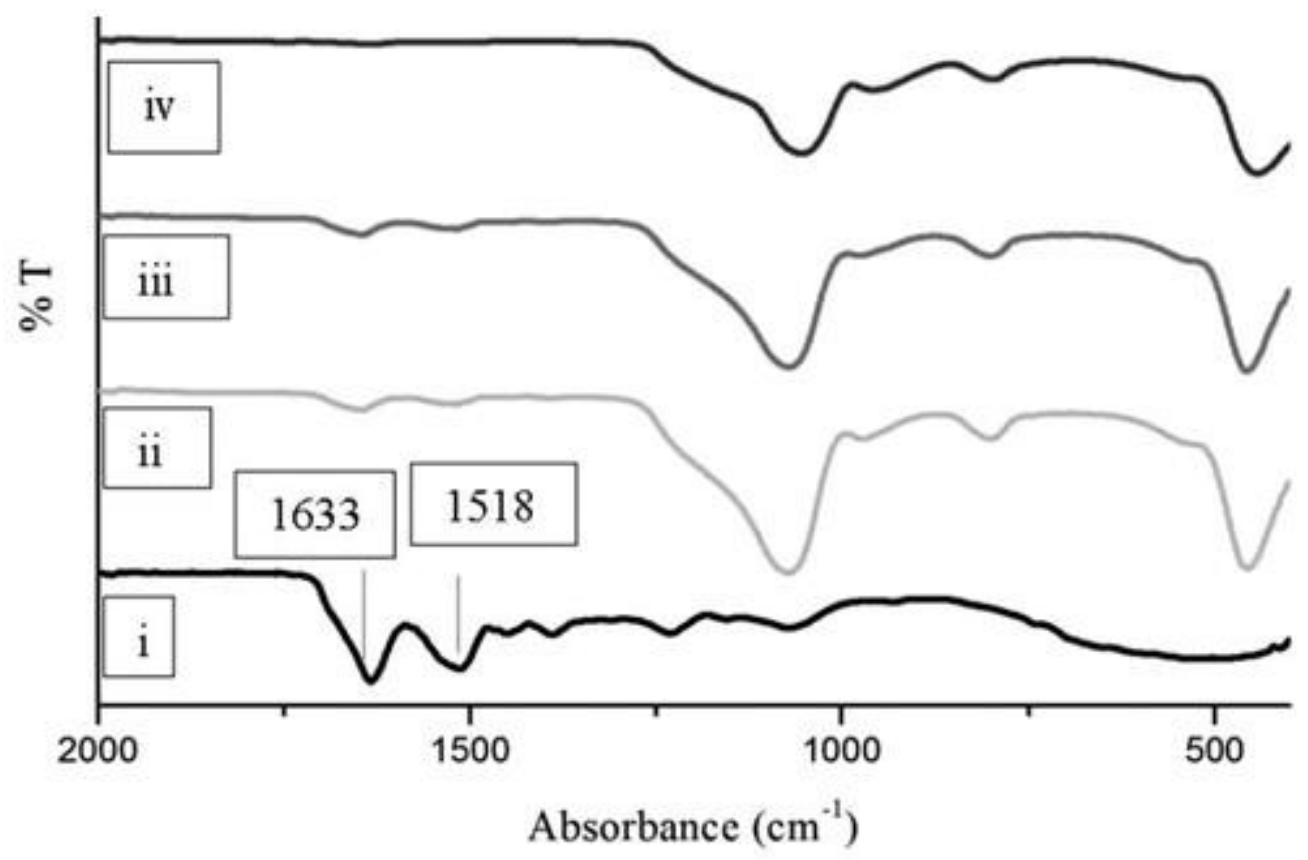

Figure 6: Desorption of $\mathrm{p}$-globulin from SFP at (A) pH 6.8 and (B) 7.4
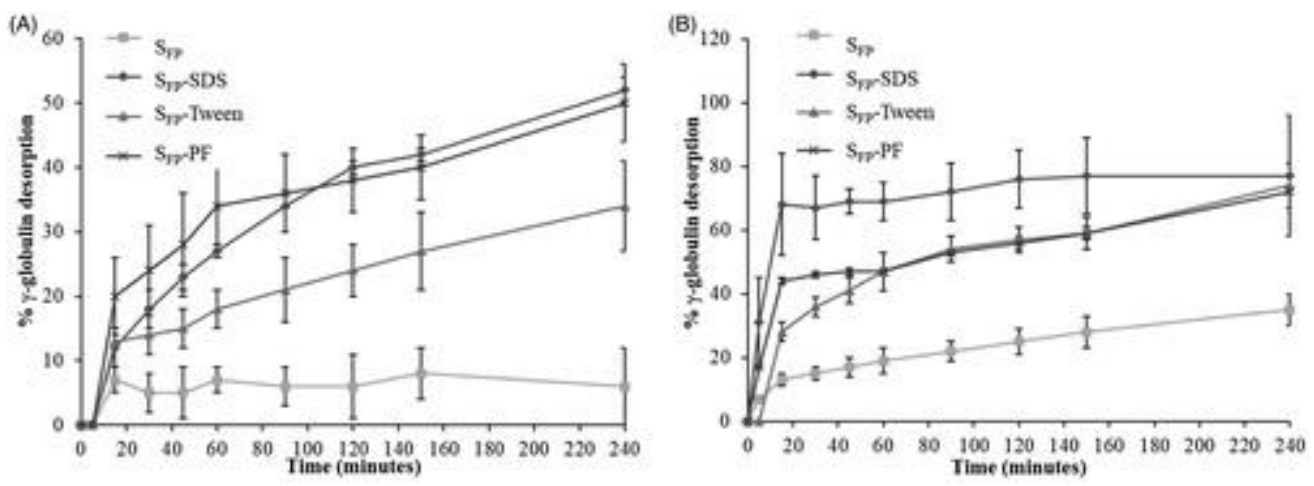

Figure 7: Desorption of $\gamma$-globulin from SXDP at (A) pH 6.8 and (B) 7.4
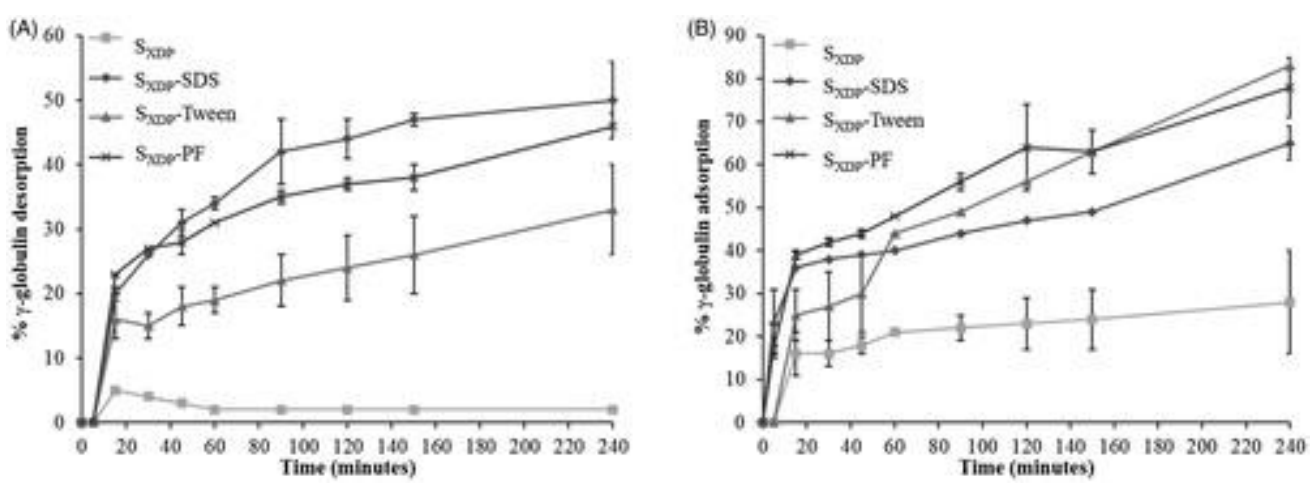
Figure 8: $\mathrm{CD}$ spectra for $\gamma$-globulin desorbed at $\mathrm{pH} 6.8$ from (A) SFP and (B) SXDP
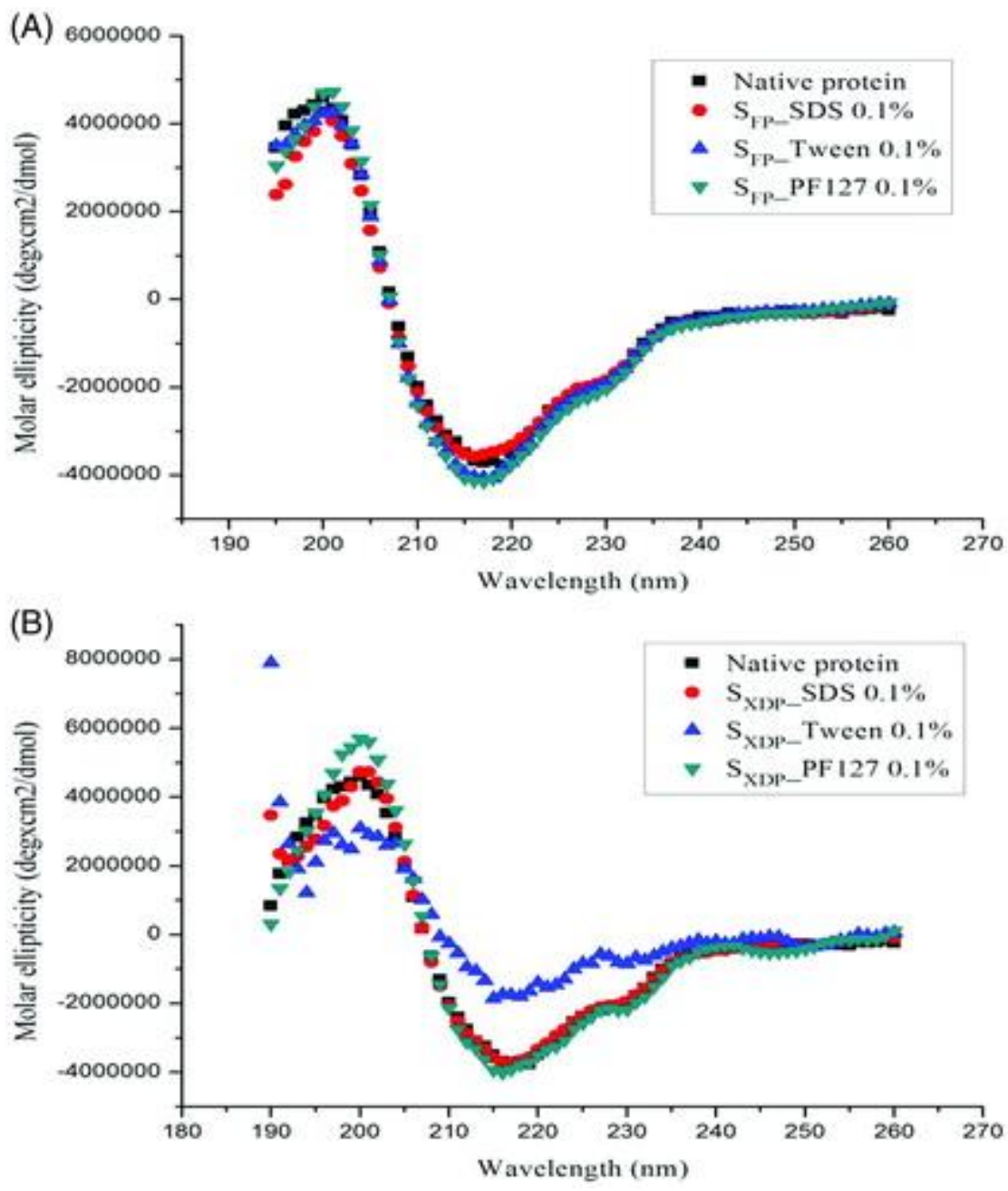
Figure 9: CD spectra for $y$-globulin desorbed at $\mathrm{pH} 7.4$ from (A) SFP and (B) SXDP
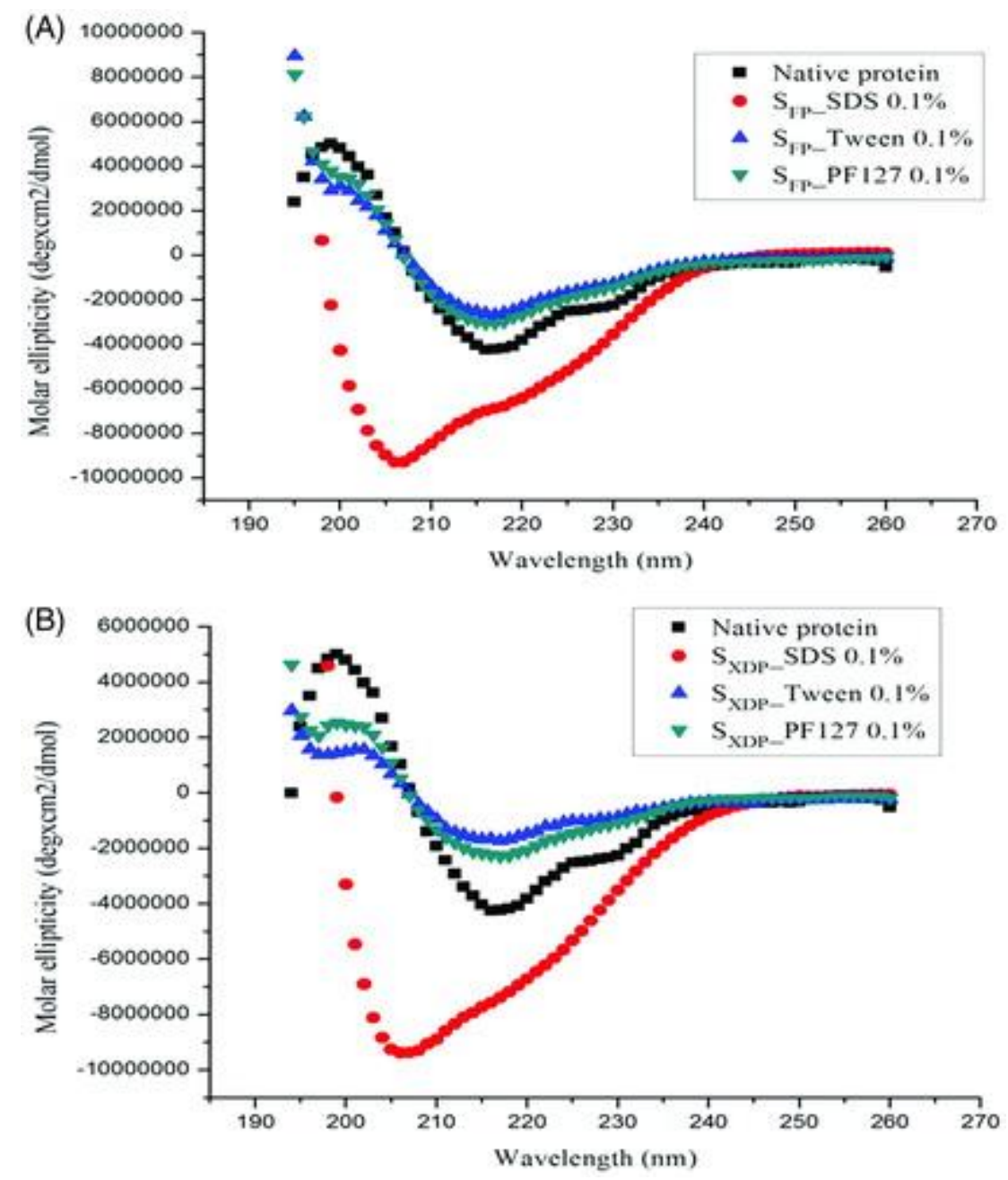

Table 1: Characteristics for SFP, SXDP, and SAL particles
Silica
SFP SXDP SAL
Quantity of adsorbed nitrogen (cm3/g STP) $892 \quad 996 \quad 260$
BET surface area (m2/g)
$289 \quad 258 \quad 767$
BJH cumulative pore volume $(\mathrm{cm} 3 / \mathrm{g})$
$\begin{array}{lll}1.35 & 1.44 & 0.40\end{array}$
BJH pore diameter $(\mathrm{nm})$
$19.122 .2 \quad 2.5$
$\mathrm{SiO} 2$ (dried basis)
$99.6 \% 99.6 \% 99.6 \%$
Average particle size $(\mu \mathrm{m})$
$3.5 \quad 50 \quad 7.5$
Bulk density (g/L)
$70 \quad 275 \quad 566$ 
Table 2: R2 values for Langmuir model plots of $\gamma$-globulin adsorption on silica particles MaterialpH $5 \quad \mathrm{pH} 6 \quad \mathrm{pH} 7.4 \mathrm{pH} 9$

SFP $\quad 0.97480 .99990 .99640 .9664$

SXDP $\quad 0.99280 .99990 .98710 .8073$

SAL $\quad 0.97010 .83260 .99810 .8984$

Table 3: R2 values for Freundlich model plots of $\gamma$-globulin adsorption on silica particles MaterialpH $5 \quad \mathrm{pH} 6 \quad \mathrm{pH} 7.4 \mathrm{pH} 9$

SFP $\quad 0.88600 .74320 .95520 .9309$

SXDP $\quad 0.63530 .63700 .89150 .8787$

SAL $\quad 0.89060 .75720 .99700 .9718$

Table 4: Surface characteristics for $\gamma$-globulin adsorbed-SFP, SXDP, and SAL particles SFP $\gamma$-globulin- SFPSXDP $\gamma$-globulin-SXDPSAL $\quad \gamma$-globulin-SAL

Quantity of adsorbed N2 (cm3/g STP) 892393 966612 260266

BET surface area $(\mathrm{m} 2 / \mathrm{g})$ 289161

$258 \quad 187$ 767703

BJH cumulative pore volume (cm3/g) 1.350 .60

1.440 .93

0.400 .42

BJH pore diameter $(\mathrm{nm})$

19.114 .8

22.219 .1

$2.5 \quad 2.6$

Table 5: PZC for $\gamma$-globulin-adsorbed silica particles

MaterialSFP $\gamma$-globulin- SFP SXDP $\gamma$-globulin-SXDPSAL $\gamma$-globulin-SAL
PZC $\quad 0.804 .80$
1.604 .50
1.104 .0

Table 6: Desorption of $y$-globulin from SFP at 240 minutes

$\mathrm{pH}$

Displacer $6.8 \quad 7.4$

None $\quad 6 \pm 6 \% \quad 35 \pm 5 \%$ 
SDS

$52 \pm 2 \% 77 \pm 19 \%$

Tween $8034 \pm 7 \% 74 \pm 7 \%$

PF127

$50 \pm 6 \% 72 \pm 0.1 \%$

Table 7: Desorption of $\gamma$-globulin from SXDP at 240 minutes

$\mathrm{pH}$

Displacer $6.8 \quad 7.4$

None $\quad 2 \pm 1 \% \quad 28 \pm 12 \%$

SDS $\quad 50 \pm 6 \% 65 \pm 4 \%$

Tween $8033 \pm 7 \% 83 \pm 1 \%$

PF127 $46 \pm 2 \% 78 \pm 7 \%$

References

AzoNano. [Internet]. Manchester (UK): Silicon Dioxide, Silica (SiO2) Nanoparticles - Properties, Applications; [cited 2019 Apr 24]. Available from:

https://www.azonano.com/article.aspx?ArticlelD=3398 [Google Scholar]

Kwon S., Singh R.K., Perez R.A., et al., Chrzanowski W. Silica-based mesoporous nanoparticles for controlled drug delivery. Journal of Tissue Engineering, 2013;4:1-18 [Google Scholar]

Radin S., Chen T., Ducheyne P. The controlled release of drugs from emulsified, sol gel processed silica microspheres. Biomaterials, 2009;30: 850- 858. [Google Scholar]

Klichko Y., Liong M., Choi E., et al. Mesostructured Silica for Optical Functionality, Nanomachines, and Drug Delivery. Journal of American Ceramic Society, 2009;92 (S1): S2- S10. [Google Scholar]

Meseguer-Olmo L., Ros-Nicolàs MJ., Vicente-Ortega V., et al. A Bioactive Sol-Gel Glass Implant for In Vivo Gentamicin Release. Experimental Model in Rabbit. Journal of Orthopaedic Research, 2006;

454- 460. [Google Scholar]

Radin S., El-Bassyouni G., Vresilovic E.J., et al. In vivo tissue response to resorbable silica xerogels as controlled-release materials. Biomaterials, 2005;26: 1043-1052. [Google Scholar]

Kortesuo P., Ahola M., Karlsson S., et al. Silica xerogel as an implantable carrier for controlled drug delivery-evaluation of drug distribution and tissue effects after implantation. Biomaterials, 2000;21: 193-198. [Google Scholar]

Nechikkattu R., Park S.S., Ha C. Zwitterionic functionalised mesoporous silica nanoparticles for alendronate release. Microporous and Mesoporous Materials, 2019;279: 117-127. [Google Scholar] Peri J. B., Hensley Jr. A. L. The surface structure of silica gel. Journal of Physical Chemistry, 1968;72: 2926- 2933. [Google Scholar] 
Owens G. J., Singh R. K., Foroutan F., et al. Sol-gel based materials for biomedical applications. Progress in Materials Science, 2016;77: 1- 79. [Google Scholar]

Rabe M., Verdes D., Seeger S. Understanding protein adsorption phenomena at solid surfaces. Advances in Colloid and Interface Science, 2011;162: 87- 106. [Google Scholar]

Meissner J., Prause A., Bharti B., et al. Characterization of protein adsorption onto silica nanoparticles: influence of $\mathrm{pH}$ and ionic strength. Colloid Polymer Science, 2015;293: 33813391. [Google Scholar]

Bremera M., Duval J., Norde W., et al. Electrostatic interactions between immunoglobulin (IgG) molecules and a charged sorbent. Colloids and Surfaces A: Physicochemical and Engineering Aspects, 2004;250: 29- 42. [Google Scholar]

Larsericsdotter H., Oscarsson S., Buijs J. Thermodynamic Analysis of Proteins Adsorbed on Silica Particles: Electrostatic Effects. Journal of Colloid and Interface Science, 2001;237: 98- 103. [Google Scholar]

Gitlin I., Carbeck J. D., Whitesides G. M. Why Are Proteins Charged? Networks of Charge-Charge Interactions in Proteins Measured by Charge Ladders and Capillary Electrophoresis. Angewandte Chemie Int. Ed., 2006;45: 3022- 3060. [Google Scholar]

Spiegelberg H.L. Biological Role of Different Antibody Classes. International Archives of Allergy and Immunology, 1989;90: 22- 27. [Google Scholar]

Rankl M., Ruckstuhl T., Rabe M., et al. Conformational Reorientation of Immunoglobulin G During Nonspecific Interaction with Surfaces. Chemical Physics and Physical Chemistry, 2006;7: 837846. [Google Scholar]

Norde W., Giacomelli C. E. BSA structural changes during homomolecular exchange between the adsorbed and the dissolved states. Journal of Biotechnology, 2006;79: 259- 268. [Google Scholar]

Felsovalyi F., Mangiagalli P., Bureau C., et al. Reversibility of the adsorption of lysozyme on silica. Langmuir, 2011;27: 11873-11882. [Google Scholar]

Norde W., Anusiem A. C. I. Adsorption, desorption and re-adsorption of proteins on solid surfaces. Colloids and Surfaces, 1992;66: 73- 80. [Google Scholar]

Takahashi H., Li B., Sasaki T., et al. Immobilized enzymes in ordered mesoporous silica materials and improvement of their stability and catalytic activity in organic solvent. Microporous and Mesoporous materials, 2001;44-45: 755-762. [Google Scholar] ur of proteins, with special reference to immunoglobulins. A physicochemical study. Advances in Colloid and Interface Science, 2012;179182: 5- 13. [Google Scholar]

Norde W., Lyklema J. Interfacial behavio

Brunauer S., Emmett P. H., Teller E. Adsorption of Gases in Multimolecular Layers. Journal of the American Chemical Society, 1938;60 (2): 309-319. [Google Scholar]

Huang X., Young N. P., Townley H. E. Characterization and Comparison of Mesoporous Silica Particles for Optimized Drug Delivery. Nanomaterials and Nanotechnology, 2014;4: 1-15. [Google Scholar]

Zhang W., Li S., Zhang J., et al. Synthesis and adsorption behavior study of magnetic fibrous mesoporous silica. Microporous and Mesoporous materials, 2019;282: 15- 21. [Google Scholar] 
Sing K., Everett D., Haul R., et al. Reporting physisorption data for gas/solid systems. Pure Applied Chemistry, 1985;57: 603- 619. [Google Scholar]

Alothman Z. A. A Review: Fundamental Aspects of Silicate Mesoporous Materials. Materials, 2012;5: 2874- 2902. [Google Scholar]

Hlady V., Buijs J., Jennissen H. P. Methods for Studying Protein Adsorption. Methods in Enzymology, 1999;309: 402- 409. [Google Scholar]

Freifelder, D. Physical Chemistry for Students of Biology and Chemistry. Boston: Science Books International, Inc. 1982;639- 650. [Google Scholar]

Clemments A. M., Botella P., Landry C. C. Protein Adsorption from Biofluids on Silica Nanoparticles: Corona Analysis as a Function of Particle Diameter and Porosity. Applied Materials and Interfaces, 2015;7: 21682- 21689. [Google Scholar]

Qi W., Li X., Chen B., et al. Intramesoporous silica structure differentiating protein loading density. Materials Letters, 2012;75: 102- 106. [Google Scholar]

Lei C., Chen B., Li X., et al. Non-destructively shattered mesoporous silica for protein drug delivery. Microporous and Mesoporous Materials, 2013;175: 157- 160. [Google Scholar]

Armstrong J. K., Wenby R.B., Meiselman H. J., et al. The Hydrodynamic Radii of Macromolecules and Their Effect on Red Blood Cell Aggregation. Biophysical Journal, 2004;87: 4259- 4270. [Google Scholar]

Liu C., Guo Y., Hong Q., et al. Bovine Serum Albumin Adsorption in Mesoporous Titanium Dioxide: Pore Size and Pore Chemistry Effect. Langmuir, 2016;32: 3995-4003. [Google Scholar]

Liu B., Cao S., Deng X., et al. Adsorption behavior of protein onto siloxane microspheres. Applied Surface Science, 2006;252: 7830- 7836. [Google Scholar]

Kondo A., Oku S., Higashitani K. Adsorption of $\gamma$-Globulin, a Model Protein for Antibody, on Colloidal Particles. Biotechnology and Bioengineering, 1991;37: 537- 543. [Google Scholar]

Demanèche S., Chapel J., Monrozier L. et al. Dissimilar pH-dependent adsorption features of bovine serum albumin and $\alpha$-chymotrypsin on mica probed by AFM. Colloids and Surfaces B: Biointerfaces, 2009;70: 226- 231. [Google Scholar]

Haynes C. A., Norde W. Globular proteins at solid-liquid interfaces. Colloids Surfaces B: Biointerfaces, 1994;2: 517- 566. [Google Scholar]

Li S., Hu J., Liu B. A study on the adsorption behaviour of protein onto functional microspheres. Journal of Chemical Technology and Biotechnology, 2005;80: 531- 536. [Google Scholar]

Urabe Y., Shiomi T., Itoh T., et al. Encapsulation of Hemoglobin in Mesoporous Silica (FSM)Enhanced Thermal Stability and Resistance to Denaturants. ChemBioChem, 2007;8: 668-

674. [Google Scholar]

Schlossbauer A., Schaffert D., Kecht J., et al. Click Chemistry for High-Density Biofunctionalization of Mesoporous Silica. Journal of American Chemical Society, 2008;130: 12558- 12559. [Google Scholar]

Carlsson N., Gustafsson H., Thörn C., et al. Enzymes immobilized in mesoporous silica: A physicalchemical perspective. Advances in Colloid and Interface Science, 2014;205: 339- 360. [Google Scholar] 
Zhang T., Zhu G., Lu B., et al. Concentration-dependent protein adsorption at the nano-bio interfaces of polymeric nanoparticles and serum proteins. Nanomedicine, 2017;12: 2757-

2769. [Google Scholar]

FTIR Analysis of Protein Structure. London (UK) [cited 2019 Mar 03]; Available from:https://www.chem.uwec.edu/chem455_s05/pages/manuals/FTIR_of_proteins.pdf [Google Scholar]

Wang Z., Liu Q., Yu J., et al. Surface structure and catalytic behavior of silica-supported copper catalysts prepared by impregnation and sol-gel methods. Applied Catalysis A: General, 2003;239: 8794. [Google Scholar]

Khdary N. H., Ghanem M. A., Abdesalam M. E., et al. Sequestration of $\mathrm{CO} 2$ using Cu nanoparticles supported on spherical and rod-shape mesoporous silica. Journal of Saudi Chemical Society, 2018;22: 343- 351. [Google Scholar]

Haris P. I. Can infrared spectroscopy provide information on protein-protein interactions? Biochemical Society Transactions, 2010;38: 940- 946. [Google Scholar]

Haris P. I., Chapman D. Does Fourier-transform infrared spectroscopy provide useful information on protein structures? Elsevier Science Publications (UK), 1997;328- 333. [Google Scholar]

Welin-Klinström S., Askendal A., Elwing H. Surfactant and Protein Interactions on Wettability Gradient Surfaces. Journal of Colloid and Interface Science, 1993;158: 188- 194. [Google Scholar]

Rapoza R. J., Horbett T. A. The Effects of Concentration and Adsorption Time on the Elutability of Adsorbed Proteins in Surfactant Solutions of Varying Structures and Concentrations. Journal of Colloid and Interface Science, 1990;136: 480- 493. [Google Scholar]

La Mesa C. Polymer-surfactant and protein-surfactant interactions. Journal of Colloid and Interface Science, 2005;286: 148-157. [Google Scholar]

Lee T-H., Lin S-Y., Pluronic F68 enhanced the conformational stability of salmon calcitonin in both aqueous solution and lyophilized solid form. Biopolymer, 2011;95: 785-791. [Google Scholar]

Krivosheeva O., Dedinaite A., Claesson Per M. Salt- and pH-induced desorption: Comparison between non-aggregated and aggregated mussel adhesive protein, Mefp-1, and a synthetic cationic polyelectrolyte. Journal of Colloid and Interface Science, 2013;408: 82- 86. [Google Scholar]

Wahlgren M., Arnebrant T. Removal of lysozyme from methylated silicon oxide surfaces by a nonionic surfactant, pentaethylene glycol mono n-dodecyl ether (C12 E5). Colloids and Surfaces B: Biointerfaces, 1996;6: 63- 69. [Google Scholar]

Otzen D. Protein-surfactant interactions: A tale of many states. Biochimica et Biophysica Acta, 2011;1814: 562- 591. [Google Scholar]

Bentaleb A., Ball V., Haïkel Y., et al. Kinetics of the Homogeneous Exchange of Lysozyme Adsorbed on a Titanium Oxide Surface. Langmuir, 1997;13: 729- 735. [Google Scholar]

Norde W., Favier J. P. Structure of adsorbed and desorbed proteins. Colloids and surfaces, 1992;64: 87- 93. [Google Scholar]

Greenfield N. Using circular dichroism spectra to estimate protein secondary structure. Nature Protocols, 2006;1: 2876- 2890. [Google Scholar] 
Jafari M., Mehrnejad F., Rahimi F., et al. The Molecular Basis of the Sodium Dodecyl Sulfate Effect on Human Ubiquitin Structure: A Molecular Dynamics Simulation Study. Scientific Reports, 2018;8 (2150): 1- 15. [Google Scholar]

England J. L. Stabilization and Release Effects of Pluronic F127 in Protein Drug Delivery. Journal of Undergraduate Sciences, 2015;5: 17- 24. [Google Scholar]

Mollmann S. H., Elofsson U., Bukrinsky J. T., et al. Displacement of Adsorbed Insulin by Tween 80 Monitored Using Total Internal Reflection Fluorescence and Ellipsometry. Pharmaceutical Research, 2005;22: 1931- 1941. [Google Scholar]

Di Russo N. V., Estrin D. A., Martı' M. A., et al. pH-Dependent Conformational Changes in Proteins and Their Effect on Experimental pKas: The Case of Nitrophorin 4. PLOS, Computational Biology, 2012;8: 1- 9. [Google Scholar] 